\title{
アラミド繊維
}

1.はじめに

1974 年アメリカ連邦通商委員会比よって全芳香族ポ リアミドはアラミドと命名され脂肪族ポリアミドけイ ロン)上区別される事となった。このアラミド織維に関 する主として最近 5 年關の技術的発展にいて要約する。

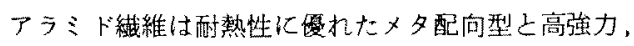
高モジュラスのパラ配向型に区分されるが，現在工業化 されている香のについて表1にまとめた。

\section{2. バラ配向型緎維}

高強力，高モジュラスを与えるパラ配向型䋐維は素材 の軽量化，小型化の社会二ーズに応え省エネルギー，省 筫源型素材として虐業資材，複合材料用途一今後益令市 場を拉大して行く志のと期待される。

とのタイプで現在上市されているのは Du Pont Kevlar ${ }^{\circledR}$ みであり，商品化されている有機轼維の中で 最高の強度，モジュラス在示す。その瀻維製造技街は己 九迄目開示された基本特许等》加ら下記の如く推定され る。即ちテレフタル酸ジクロライドとパラフェニレンジ アミンの重合により得られた高重合度のポリーpーフェニ レンテレフタルアミド(PPTA)を硫酸に溶解し光学的 翼方性ドープとなし，とれを紡系ノズルから希硫酸中に

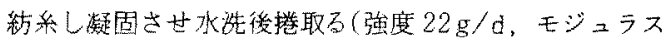
$470 \mathrm{~g} / \mathrm{d}$ )。の製系法のポイントは液晶ドープがノズ

\section{平 塚 尚三郎}

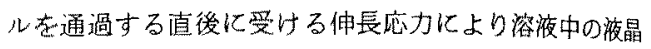
状態がそのまま維持され分子が䄉維軸方向化高度化配向

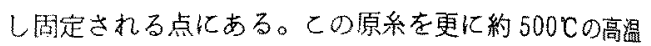
で雚処理すると高もジュラス(約 $1000 \mathrm{~g} / \mathrm{d}$ )タイプの裂 品力゙得られる。

一方AKZOは同しPPTA瀻維であるArenka ${ }^{\mathbb{B}}$ の事業 化考決定し現在工場建設中上伝元られるが，欧米汇おい

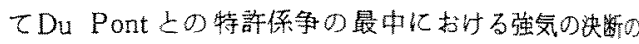
去就が注目ざれる。

PPTA織維の製造技術についてはこの他，多数の特 許が提出されている。との中でDu Pontの高速紡系(約 $1800 \mathrm{~m} /$ 分) に上る工程合理化上高性能化の徥案”，相 化成の湿潤延伸による高モジュラス化 $(1520 \mathrm{~g} / \mathrm{d})$ の提

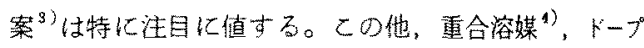

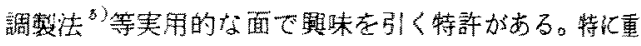
合溶媒ししては最毛溶解性の高いへキサメチルフォスフ オルアミドが発癌性の疑念に上り使用困難之なったため 新溶媒の探索加各社において精力的们行われたが，現在 ではミト柔溶媒 (Nーメチルピロリトン、ジメチルアセ トアミド等)と無機塩 $\left(\mathrm{LiCl}, \mathrm{CaCl}_{2}\right.$ 等)の組合女が主 流よなった上考えられる。

PPTA以外のポリマーに上る硫酸液晶紌系の試み百 数多く為されているが，強度，モジュラスに関し最高 值を与える例として宇部興産特䛨 ${ }^{6)}$ 亿見られる $\mathrm{tHN}-\mathrm{O}-\mathrm{O}-\mathrm{NH}_{20}+\mathrm{HN}-\mathrm{O}-\mathrm{NH}_{84} \mathrm{fOC}-\left(\mathrm{O}-\mathrm{CO}_{360}\right.$ $\mathrm{SO}_{2}$

表 1 世界のアラミド䌜維

\begin{tabular}{|c|c|c|c|c|}
\hline タイプ & 称 & $x-カ-$ & 生産開始 & 産 \\
\hline \multirow[t]{3}{*}{ ×夕配向 } & Nomex ${ }^{(B)}$ & Du Pont & 1965 & $10,000 \mathrm{~T} / \mathrm{Y}$ (今む紆 $)$ \\
\hline & TEIJINCONEX ${ }^{\circledR}$ & 1 & 1979 & $600 \mathrm{~T} / \mathrm{Y}$ \\
\hline & Fenilon & 連 & & \\
\hline \multirow[t]{2}{*}{ パラ配问 } & Kevlar ${ }^{(\mathbb{B})}$ & Du Pont & 1972 & $\begin{array}{l}7,000 \mathrm{~T} / \mathrm{Y} \text { を } 22,000 \mathrm{~T} / \mathrm{Y} \\
\text { に能力增('83) }\end{array}$ \\
\hline & Arenka ${ }^{(8)}$ & $\mathrm{AKZO}$ & $\begin{array}{c}1984 \\
\text { (工場建設中) }\end{array}$ & $5.000 \mathrm{~T} / \mathrm{Y}$ \\
\hline
\end{tabular}

Aramid Fibers

SHOSABURO HIRATSUKA

TEIJIN LIMITED, Products Development

Research Laboratories

帝人株式会社生産技術研究所 主席研究員 
の强度 $37.5 \mathrm{~g} / \mathrm{d}(モ シ ゙ ュ ラ ス 971 \mathrm{~g} / \mathrm{d})$ 及び坦化成制 ${ }^{7} の$ $\mathrm{tNH}-(0-0)-\mathrm{NHF}_{30}-\mathrm{NH}-0$ - $\mathrm{NH}_{90}-\mathrm{OC}-\left(\mathrm{O}-\mathrm{COt}_{100}\right.$ によるモジュラス $1320 \mathrm{~g} / \mathrm{d}$ (強度 $25 \mathrm{~g} / \mathrm{d}$ ) 肪ある。

一方有機(アミド愻)溶媒を用い等方性ドープから紡 柇熱延伸に上り同様の高性能を有する織維を得上う とする試みあ数多く為されている。帝人の HM- 50

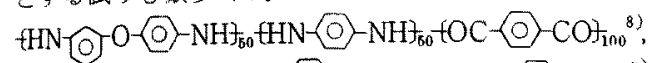
Monsanto $0 \mathrm{X}-500 \mathrm{HN}-0-\mathrm{CONHNHCO}\langle 0\rangle \mathrm{CO}^{*}$. 東レの+HN-O-O-O- $\mathrm{NH}_{30}+\mathrm{HN}-\mathrm{O}-\mathrm{Cl} \mathrm{NH}_{36}$ $\mathrm{tHN}-\mathrm{O}-\mathrm{NH} \mathrm{T}_{85}, \mathrm{OC}-\left(\mathrm{O}-\mathrm{CO}_{100}{ }^{10}\right.$ 等は大の代表的な 洌であり前記液晶紡系に対抗して高性能を発現させる新 しい方式として今後の展開が期待される。

\section{3. ×夕配向型緉維}

ポリーmーフェニレンイソフタルアミド(PMIA)織維 の整造はD u Pont之帝人において夫々独自の方法に上 って行われて㧍り基本技術は確立されたと考えられる。 又ソ連のFenilonの製造技術内容も最近の特許，報文加 ら同い知る事が出来る。

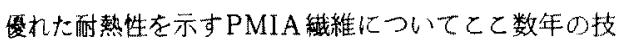
術的改良は染色性，耐光性，難然性，䡎资性等の向上に 関するものが主体である。PMIA瀻維を産業資材分野 のみならす衣料用途，インテリア用途汇も展開して行と うとする機谨に沿って，染色性については原着系及び易

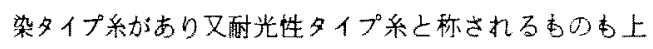
市されている。難然化，利炎化については他の合成瀻䧽 と刘比して本来この織維が有する優れた性能を更に向上 させる事になるが八ロゲン，燐化合物といった難燃剤を 紡系ドープ練り込む方法 ${ }^{11}$ ，或はこ机らの郕を䄉維に 含浸させる方法 ${ }^{12}$ 等の他に，䄉維，織物の表面をこれ らの剂で化学处理するMonsantoのDurette が知られて いる。最近Du Pont ではNomex ${ }^{\mathbb{B}}$ 瀻維䎲Kevlar ${ }^{\mathbb{B}}$ 紻維 を低率混紀し耐资性を向上させた織物を開発している

\section{4. アラミドに関する学術的研究}

パラ配向アラミド溶液加液晶となり，乙れを紡系する 事によって高性能轹維が得られるという Du Pont 研究 者の発明力学術的な研究の分野においても大きな刺激上 なった。溶液の光学翼方性に関する多くの研究報告か 為されて㧍り ${ }^{(4)}$, 又PPTAの䋐維構造についても所謂

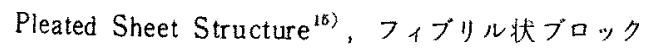
構造モデル ${ }^{16)}$. Skin-Core構造モデル ${ }^{17)}$ 等の提案が為 されており今後も議論を呼ぶ処であ万う ${ }^{18)}$ 。

一方リママー及び合成法の面については現在工業的に 実施されている芳香酸クロライトとジアミンによる 重縮合反沉以外にジカルボン酸とジアミンから直接ポリ

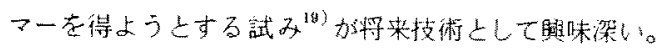

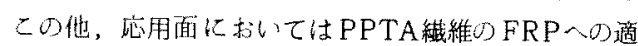
用が実用化されるに伴い，乙れら襩合材料関連心研究活 動息極めて活発となって来た。基秝的な面での研究例亡 して汎用ポリマーにPPTA繊維等心㴊直銷ポリマーを ミクロ均一分散させ力学特性を向上させようとするモレ キュラーコンポジットの提案 ${ }^{30)}$ 汃注目される。

\section{5. おわりに}

以上述へて来た如く性能的に見ればアラミド瀻維の将

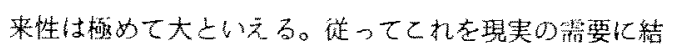
びつけ発展させて行くためにはもう一つの技術要素であ る製品コストが他素材対比どれだけ競争力を有ずるかが ポイント上なる。更にアラミド発㞗のもう一つの鍵はそ の優れた特性を生かしどれだけ新しい用途初野を開拓出

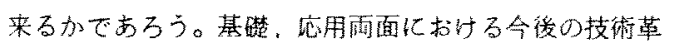
新に期待したい。

\section{参考文献}

1) USP: $3,063,966,3,850,888,3,671,542,3,673,143$ $3,767,756,3,869,429,3,933,963,3,869,430$

2) USP : 4,340,559

3）特公昭 55-11764

4) 特開昭 51-109099, 特開昭 52-71593, 特開略 5311994 , 特開昭 57-164151

5) 特開昭 56-313

6) 特開昭 $53-98416$

7) 特公昭 55-11763

8) 特閒昭 51-136916

9) 特公略 48-6415

10）特椫昭 55-22052

11）特公昭 55-26206，特開昭 52-82955

12) USP : $4.162,275$

13) USP : $4,198,494$

14) 列芫ば，J.R. Schaefgen, et al., "Rigid Chain Polymers: Properties of Solutions and Fibers" in A. Ciferri et al. eds., Ultra-High Modulus Polymers, Chapt. 6, Applied Science Publishers, London, 1979, 173-201

15) M. G. Dobb et al., J. Polym. Sci., Phys. Ed., 15, 2201 (1977)

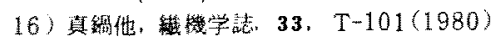

17) C. O. Pruneda, et al., ACS Polymer Prep., $22(2)$, 216 (1981)

18) 高橋, 裁学誌 $37(9), P-325(1981)$

19）東，有機合成化学势会誌，40，922(1982)

20) 特開昭 54-65747

㥀 1980 年 9 月時点汽の技征動问以ついては下記の詳細な棕 説があるので参考頂き度い。 島田, 米良: 阵学誌, 37，P-125(1981)

(昭和 58 年11月 1 日受理) 